\title{
Maximizing Economic Performance in the Mining Industry by Applying Bioleaching Technology for Extraction of Polymetallic Mineral Deposits
}

\author{
Daniel Kržanović *, Vesna Conić, Dejan Bugarin, Ivana Jovanović and Dragana Božić \\ Mining and Metallurgy Institute Bor, Zeleni bulevar 35, 19210 Bor, Serbia \\ * Correspondence: daniel.krzanovic@irmbor.co.rs
}

Received: 29 May 2019; Accepted: 27 June 2019; Published: 28 June 2019

check for updates

\begin{abstract}
There are many sources to increase value in an integrated mining-metallurgy context. The optimal strategy for concentration of minerals from the ore is one of these sources. The elements of mining-metallurgy operations from resources, infrastructure, mining site, processing, and metallurgy are mutually dependent, and reinforce and interact positively with each other to generate a combined value greater than the sum of their individual contributions. Bioleaching technology is an alternative processing technology for treatment of low-grade sulphide ore, and its application contributes to the achievement of better economic results than the conventional pyrometallurgical technology. This work presents the application of bioleaching technology in laboratory conditions for metal extraction from the polymetallic deposit Tenka in East Serbia, belonging to the company Serbia Zijin Bor Copper Doo (formerly the Mining Smelter Basin Bor Group). Bioleaching of sulphide polymetallic raw material is performed by chemolithoautotrophic microorganisms. Applying the bioleaching technology, the achieved recoveries of metals from the polymetallic ore are as follows: $\mathrm{Cu} 90 \%$, Au 90\%, Ag 80\%, Zn 72\% and Pb 90\%. The calculated values for Net Present Value (NPV) and Internal Rate of Return (IRR) are \$ 21.927 million and $12.55 \%$, respectively.
\end{abstract}

Keywords: integrated mining-metallurgy complex; strategic mine planning; bioleaching technology; polymetallic ore; NPV maximization

\section{Introduction}

Strategic planning for mineral resources acknowledges the importance of the mineral raw materials that contribute to progress and development, ensure a high living standard and create a competitive national and regional economy and new job positions.

In economically developed countries, the law regulates that mining companies must operate in a way that is in the best interest of shareholders. This implies that the management of a company is obliged to design and manage all mining and processing operations in a way as to ensure the maximum profit to the shareholders during the course of these operations, taking into account the time effect of money value. Despite the importance of economic issues the environmental concerns cannot also be neglected. Environmental issues may include land use, management and rehabilitation, solid waste, water use, acid mine drainage, product toxicity, etc.

A integrated mining complex consists of multiple components such as mines, crushers, stockpiles, leach pads, processing mills, waste dumps, metallurgical plants, means of transportation and customers. The components are interlinked to form the mineral value chain. Material extracted from the mines flows through the mineral value chain to finally produce the products which are delivered to customers and/or spot market [1].

By analyzing the value chain, the mining company may have knowledge of what nature of insights can be gained, which can have a pronounced impact on the firms operating in this industry. 
These insights can be used by firms in the industry to shape their strategy in helping to improve its financial performance.

Today, with the application of computer programs based on methods of mathematical programming, it is possible to create better plans. The consequence of this is to achieve significantly better results in the exploitation and treatment a low grade ore in complex operating conditions [2].

Material flows, which determine the revenues obtained from the final product and the operating costs, depend on several factors, including the nature of deposits, mining technology, processing characteristics (crushing and grinding) and metallurgy technology (bioleaching).

Processing of polymetallic complex low-grade ores has an important role in modern research in terms of the ability to achieve higher recoveries of metal values from such mineral resources [3-5].

For material characterization, the raw material which will be treated in this investigation is polymetallic rich ore which contains $\mathrm{Cu}, \mathrm{Zn}, \mathrm{Pb} \mathrm{Ag}$ and $\mathrm{Au}$. This ore is known as SEDEX type of ore (Rammelsberg and Meggen in Germany and Red Dog in Alaska, have this type of ore) [6-11]. The ore is vary compact and minerals are tightly impregnated between them. The main problem of this type of ore is whether it will be opened for flotation. From this reason, we chose SEDEX ore for investigation.

The first step in the aim of future technology investigation is to find ore, take a sample, and prepare the sample (the ore must be crushed and milled to appropriate size composition) for complete mineralogical, physical and chemical characterization and future investigations.

Biomining is a well-established technology for extracting metals from low-grade and polymetallic base metal ores, and refractory gold ores [12]. For the biomining of gold and some other precious metals, micro-organisms are used to remove minerals that occlude target metals which are solubilized in a second process (e.g., by extracting with cyanide or thiosulfate in the case of gold) [13].

One of the roles of acidophilic chemolithotrophic bacteria is to accelerate the oxidative dissolution of sulfide minerals and extracting metals from sulfidic ores and concentrates.

Bioleaching techniques have to compete with alternative pyrometallurgical and pressure-leaching technologies for extracting metals from ores and concentrates which often represent major investments by mining companies [14].

Advantages of biomining is that it is an environmentally acceptable technology which involves much lower temperatures (and hence energy costs) and smaller carbon footprints. The micro-organisms involved in mineral oxidation processes are autotrophs and they fix carbon dioxide, in the same way as green plants, what is in the contrasts with smelting operations that emit large amounts of $\mathrm{CO}_{2}$. Bioleaching also operates at atmospheric pressure and at relatively low temperatures $\left(20-80^{\circ} \mathrm{C}\right)$. The advantage of this technology is also seen to be suitable for treatment of low-grade and complex polymetallic ore or concentrate which contains significant quantities of arsenic, cadmium and mercury (which is released in gaseous emissions during smelting but retained in liquid and solid phases in biohydrometallurgical processing $[15,16]$. Biomining also allows metal by-products (such as silver) to the more readily recovered from processed ores than is the case with waste slags generated by pyrometallurgy.

Usually, an external heat source is not necessary for the oxidation of sulfide minerals, because it is an exothermal process. Excess heat is generated where rates of oxidation are intense (as in stirred tank operations) and systems require to be cooled to maintain suitable temperatures for the mineral-degrading micro-organisms (generally $40-45^{\circ} \mathrm{C}$ ) in these systems [17].

Solving the problem of exploitation and processing of polymetallic ores implies consideration of all relevant parameters and factors (ore deposit geology, production process technology, digging and processing capacity, costs, metal prices, use, etc.) in order to achieve the set goal. The increasing focus on bioleaching technology is leading to an increase in the amount of information that may be taken into account to optimise operating strategies.

This paper focuses on the application of bioleaching technology for the treatment of polymetallic ores in order to achieve maximum profit in an integrated mining complex such as at the Serbia Zijin Bor Copper Doo company (formerly the Mining Smelter Basin Bor Group). 


\section{Materials and Methods}

\subsection{Concept of Research Work}

Profitability is ability of a company to use its resources to generate revenues in excess of its expenses. In other words, this is a company's capability of generating profits from its operations. In the case of a metal mining company, achieving this goal requires significant evaluation and planning.

First, it must be determined what portion of the deposit is economical to mine; in other words, the mineable reserve. Then, considerable effort must be made in planning and scheduling the extraction of the mineable reserve. The next stage is the determination of the methods and characteristics of the processing. Finally, it is very important to determine the metallurgical technology. The aim of this attempt is to determine the most profitable plan which maximizes the Net Present Value [18].

In a complex mining-metallurgy system, like the Serbia Zijin Bor Copper Doo company, its components can be integrated into the Mining Industry Value Chain, with the aim of increasing the economic value of the metal acquisition process in long-term planning [19-22]. Value chain analysis is a process where a mining company identifies its primary and support activities that add value to its final product and then analyze these activities to reduce costs or maximizing metal recovery from ore mined. A decision made at any stage in the chain potentially influences the optimal solution for all other stages. There is little or nothing that a mining company can do to improve the resource in the ground or the international market for the products, but all the other steps can potentially influence the maximization of NPV.

\subsection{Mineral Deposit}

The basic primary input in the strategic planning process in the mining industry is a geological block of the ore body. In this paper, the laboratory research on application the bioleaching technology has been carried out on the ore samples from the Tenka deposit, which consists of the ore bodies Tenka 1 and Tenka 2. From the results of chemical and mineralogical analysis of the ore, it can be seen that the treated sample is polymetallic $\mathrm{Zn}, \mathrm{Cu}, \mathrm{Pb}, \mathrm{Ag}$, and $\mathrm{Au}$ sulphide ore.

The geological structure of the Tenka deposit involves: crystalline shales of amphibolitic facies, rocks of green shale facies, titanium valendine limestones, Upper Cretaceous volcanites, products of the Laramian plutonism, skarns and skarnoids and tectonic breccias.

The polymetallic ore of the ore bodies Tenka 1 and Tenka 2 is characterized by diverse and complex mineral associations. The most common metal minerals are pyrite and sphalerite, followed by galenite, chalcopyrite, pyrrhotite, marcasite, bornite, chalcocite, tetrahedrite, native gold, electrum, covellite, lindstrumite, hessite, petzite, tennantite, braunite, enargite, magnetite, realgar, and polybasite and stephanite.

Based on the results of chemical analyses of individual tests from the exploratory drill holes drilled in the Tenka deposit, the mean content was calculated separately for each ore body, as shown in Table 1.

Table 1. Average grade of metal in the deposit of polymetallic ore Tenka.

\begin{tabular}{cccccc}
\hline \multirow{2}{*}{ Ore Body } & \multicolumn{5}{c}{ Average Grade of Metal in the Ore } \\
\cline { 2 - 6 } & $\mathbf{C u ~ ( \% )}$ & $\mathbf{A g} \mathbf{~ ( g / t )}$ & $\mathbf{A u ~ g / t}$ & $\mathbf{Z n ~ ( \% )}$ & $\mathbf{P b ~ ( \% )}$ \\
\hline Tenka 1 & 0.184 & 9.891 & 0.552 & 1.623 & 0.535 \\
Tenka 2 & 0.295 & 7.349 & 0.793 & 1.647 & 0.276 \\
\hline Middle value & 0.221 & 9.045 & 0.632 & 1.631 & 0.449 \\
\hline
\end{tabular}

A block model for the Tenka deposit was created with separate attributes of metal content in the polymetallic ore, which are interesting from the economic point of view. Thus, the attributes of $\mathrm{Cu}, \mathrm{Au}$, 
$\mathrm{Ag}, \mathrm{Pb}$ and $\mathrm{Zn}$ contents were formed. In the process of modeling the ore bodies, the kriging method was used to estimate the metal content representing the geostatistic interpolation method $[23,24]$.

\subsection{Ore Characterization}

Mineralogical analysis of the ore and bioleach residue was performed using the X-ray diffraction (XRD) Explorer model analyser (GNR) with $\mathrm{Cu} \mathrm{K} \alpha(0.154 \mathrm{~nm})$. The operating conditions are $40 \mathrm{kV}$ and $30 \mathrm{~mA}$. The mineralogical XRD pattern is presented in Figure 1, where it can be seen that the ore mostly consists of sphalerite $(\mathrm{ZnS})$, chalcopyrite $\left(\mathrm{CuFeS}_{2}\right)$, galena $(\mathrm{PbS})$, and pyrite $\left(\mathrm{FeS}_{2}\right)$.

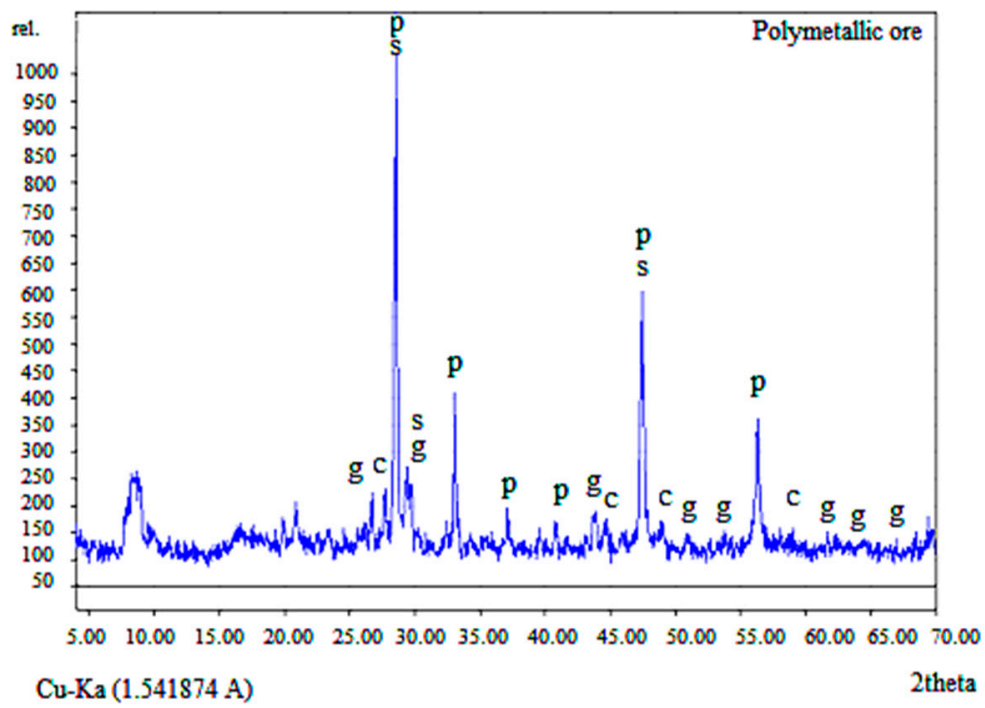

Figure 1. X-ray diffraction pattern of the concentrate where $\mathrm{p}-$ pyrite; $\mathrm{s}$-sphalerite; g-galena and c-chalcopyrite.

\subsection{Microbiological Culture}

Mesophilic mixed bacterial culture of At. ferrooxidans, At. thiooxidans, and Leptospirillum ferrooxidans was isolated from underground mine water of the Bor Copper Mine in Serbia. The Bacterial growth was observed on an Carl Zeiss microscope with phase contrast. A sample of mine water was taken from the ore body "Tilva Roš".

Characterization of microbiological species presented in mine waters was conducted using quantitative polymerase chain reaction (Q-PCR) analysis-based molecular equipment, and determination of their number was done applying the Q-PCR and T-RFLP methods. The natural microbial population in Serbia Zijin Bor Copper Doo company mine waters is listed in Table 2, from which it can be seen that the relative presence of cultures which exist in natural mine habitats is not large.

Table 2. Quantification of microbial population using Q-PCR.

\begin{tabular}{ccc}
\hline \multicolumn{2}{c}{ Natural Population of Bacteria in Serbia Zijin Bor Copper DOO Company Mine Waters } \\
\hline Program for PCR Analysis & Target-PCR & Bacteria, cells/mL \\
\hline P363P364 & Acidithiobacillus ferrooxidans & $2.3 \times 10^{4}$ \\
P353P354 & Acidithiobacillus thiooxidans & $2.3 \times 10^{4}$ \\
P071M041 & Leptospirillum ferrooxidans & $2.3 \times 10^{4}$ \\
\hline
\end{tabular}

\subsection{Culture Media}

Culture media that is used in the bioleaching experiment for growing bacteria was $9 \mathrm{~K}$, and consisted (g/L): $\left(\mathrm{NH}_{4}\right)_{2} \mathrm{SO}_{4}-2.25 ; \mathrm{Na}_{2} \mathrm{SO}_{4} \cdot 10 \mathrm{H}_{2} \mathrm{O}-7.5 ; \mathrm{KCl}-2.5 ; \mathrm{MgSO}_{4} \cdot 7 \mathrm{H}_{2} \mathrm{O}-25 ; \mathrm{KH}_{2} \mathrm{PO}_{4}-2.5 ; \mathrm{Ca}\left(\mathrm{NO}_{3}\right)_{2}$. 
$4 \mathrm{H}_{2} \mathrm{O}-$-0.7. Acidity of media, using $1 \mathrm{M} \mathrm{H}_{2} \mathrm{SO}_{4}$ p.a. quality, was set up to $\mathrm{pH} 2$ at the beginning of the bioleaching test.

\subsection{Glass Reactors}

In bioleaching experiment four independent glass reactors was used in discontinuous work. The total volume of each reactor was $2 \mathrm{~L}$, thereof $1 \mathrm{~L}$ was working volume. To verify the results of bioleaching three reactors are operated under the same conditions. One reactor was control that was not inoculated. The temperature in experiment is maintain on $30^{\circ} \mathrm{C}$, stirring speed was $250 \mathrm{r} / \mathrm{min}$. Air and carbon dioxide are introduced with the aim of using oxygen $0.5 \mathrm{NL} / \mathrm{min}$ and $\mathrm{CO}_{2}=20 \mathrm{~mL} / \mathrm{min}$, respectively through diffusers.

\subsection{Cultivation of Micro-Organisms}

To enrich micro-organisms from environmental samples, four liquid media were prepared:

1. Ferrous sulphate medium for enrichment of autotrophic iron oxidizers $(1 \times$ basal salts, $25 \mathrm{mM}$ ferrous sulphate)

2. Ferrous sulphate/yeast extract medium for enrichment of autotrophic iron oxidizers and heterotrophic acidophiles $(1 \times$ basal salts, $0.02 \%$ yeast extract, $25 \mathrm{mM}$ ferrous sulphate)

3. Pyrite medium for enrichment of Leptospirillum sp $(1 \times$ basal salts, $1 \mathrm{~g}$ of pyrite $)$

4. Yeast extract medium for enrichment of heterotrophic acidophiles $(1 \times$ basal salts, $0.02 \%$ yeast extract)

Basal salts solution, $50 \times$ concentrated $(\mathrm{g} / \mathrm{L}):\left(\mathrm{NH}_{4}\right)_{2} \mathrm{SO}_{4}-2.25 ; \mathrm{Na}_{2} \mathrm{SO}_{4} \cdot 10 \mathrm{H}_{2} \mathrm{O}-7.5 ; \mathrm{KCl}-2.5$; $\mathrm{MgSO}_{4} \cdot 7 \mathrm{H}_{2} \mathrm{O}-25 ; \mathrm{KH}_{2} \mathrm{PO}_{4}-2.5 ; \mathrm{Ca}\left(\mathrm{NO}_{3}\right)_{2} \cdot 4 \mathrm{H}_{2} \mathrm{O}-0.7$.

Each of four enrichment media were inoculated with $1 \mathrm{~mL}$ of acidic water samples (labelled as $\mathrm{J}$ and B) and those eight flasks were incubated at constant temperature of $30^{\circ} \mathrm{C}$. After 30 days of incubation a colour change of the liquid media has been apparent in all flasks, indicating bacterial growth. These enriched environmental samples were used further for adaptation experiments.

Micro-organisms were adapted to growth on polymetallic mineral substrate in three subsequent transfers of micro-organisms to fresh nutrient media with increasing concentrations of mineral substrate which acted as source of energy for bacteria.

\subsection{Analytical Determinations}

The concentration of copper and zinc, in solution were measured every three days by absorption spectrometry (Perkin-Elmer 403). Expanded uncertainties of concentrations are $\pm 8.8 \%$ and $\pm 7.5 \%$ for copper and zinc respectively. The value of oxidation-reduction potential (ORP) was measured by $\mathrm{Pt}$ electrode in relation to a $\mathrm{Ag} / \mathrm{AgCl}$ reference electrode $(\mathrm{mV})(\mathrm{vs} . \mathrm{Ag} / \mathrm{AgCl})$. The acidity of the solution was measured by combined $\mathrm{pH}$ electrode. XRD analysis of the fine-milled samples was conducted before and after the bioleaching process.

\subsection{Goals and Value Measures}

A block model partitions the deposit into discrete areas of valuable ore blocks and unprotable waste blocks, enabling researchers to select suitable mining methods and to perform strategic mine planning, which include open pit optimization and schedule optimization.

Open pit optimization involved identifying combinations of controlled variables which maximize the value of the project in the context of a given set or range of assumptions. In this case, study the open pit optimization was carried out in the Whittle (Dassault Systèmes GEOVIA), a software package that applies pit parameterization technique for generating nested pits [25-30]. The parameterization approach enables us to present various alternative pit designs to the user so that the best plan, as defined by a specific combination of parameters (metal prices, recoveries, mining and processing costs, etc.) can be selected. 
With the goal of maximizing the Net Present Value (NPV), the block sequencing problem endeavors to determine the most efficient extraction sequence of the polymetallic ore [31]. This NPV is the sum of all the extracted blocks' discounted net profits. A block's profit is calculated as the market value of the ore in the block minus the costs of removing and processing the material in the block, and then discounting this number based on the time of extraction and an appropriate discount factor.

As it is known, in the mining industry, any project has to have a long-term feasibility calculation. The proof of feasibility is typically demanded at the least by the potential investors and creditors. The traditional Discounted Cash Flow (DCF)—based methods are still regarded as an industry standard when evaluating the value of the mining operation. Net Present Value is calculated in the software Whittle by discounting the estimated annual cash flows at the present time using the discount rate, which represents the risk of investing:

$$
\text { Net Present Value (NPV) }=\sum\left[C F_{t} /(1+k)^{t}\right]-I, \text { for } t=0, \ldots, n
$$

where $C F_{t}$ is the Cash Flow (revenues less costs) for year $t, k$ is the constant discount rate representing the risk over the operation life and $I$ is the initial capital expenditure.

Internal Rate of Return (IRR) is calculated by solving the following equation for $k$ :

$$
\text { Internal Rate of Return }(\mathrm{IRR})=\mathrm{NPV}=0=\sum\left[C F_{t} /(1+k)^{t}\right]-I \text {, for } t=0, \ldots, n
$$

\section{Results and Discussion}

\subsection{Bioleaching Experiments}

\subsubsection{Adaptation I}

Four $250 \mathrm{~mL}$ flasks were used in the adaptation experiment. Solution for adaptation of bacteria was prepared with $4 \times 98 \mathrm{~mL} \mathrm{H}_{2} \mathrm{O}$ dist. and $3 \times 2 \mathrm{~mL}$ of $50 \times$ concentrated basal salts solution, and $\mathrm{pH}$ value was set up at 2 . Three flasks were inoculated with $1 \mathrm{~mL}$ samples from four enrichment media, while the fourth flask was a non-inoculated control. The adaptation was done in a Heidolph shaker at temperature of $30^{\circ} \mathrm{C}$ and stirring speed of $150 \mathrm{rpm}$. The solid phase content in the flask was $5 \%(w / v)$. Figure 2 shows changes of $\mathrm{pH}$ and $\mathrm{Eh}(\mathrm{mV})$ in time (days).

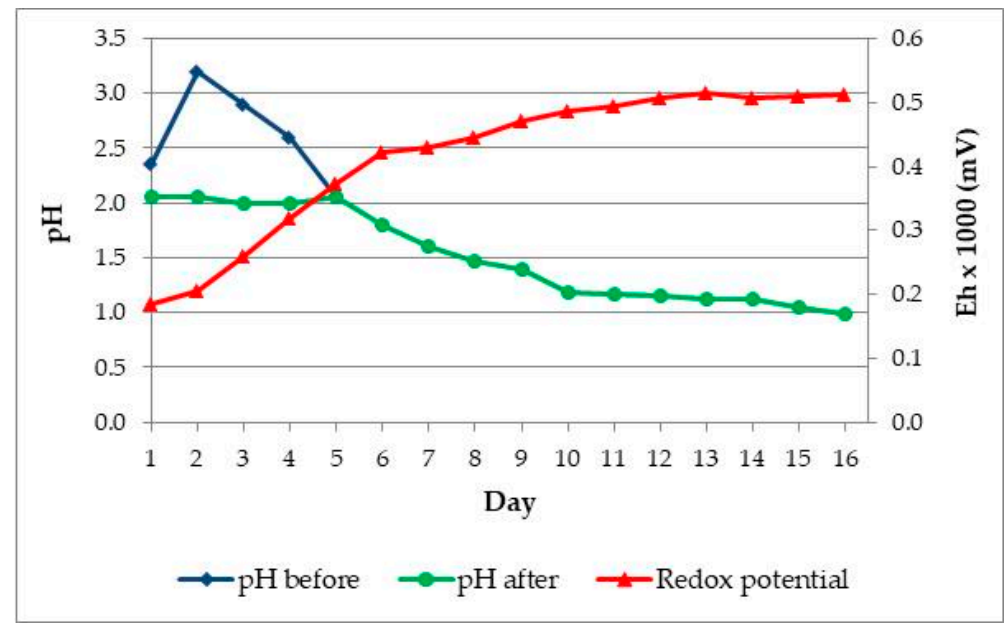

Figure 2. Changes in $\mathrm{pH}$ and $\mathrm{Eh}(\mathrm{mV})$ vs. time in Adaptation I. Black circles- $\mathrm{pH}$ before $\mathrm{H}_{2} \mathrm{SO}_{4}$ addition; blue squares- $\mathrm{pH}$ after $\mathrm{H}_{2} \mathrm{SO}_{4}$ addition; red triangles-Eh (mV).

After adding the ore, the $\mathrm{pH}$ value in solution increased. In general, the $\mathrm{pH}$ value increased in first four days, but it was adjusted using sulphuric acid to the initial value $\mathrm{pH}=2$. 


\subsubsection{Adaptation II}

After the first adaptation experiment, $1 \mathrm{~mL}$ of each bacterial culture from flask of the first adaptation round was transferred to flasks with fresh medium and samples of ore. The content of solid in solution was increased to $7 \%(w / v)$. Temperature and stirring speed were same as in previous experiment. Figure 3 shows changes of $\mathrm{pH}$ and $\mathrm{Eh}(\mathrm{mV})$ during the second adaptation experiment.

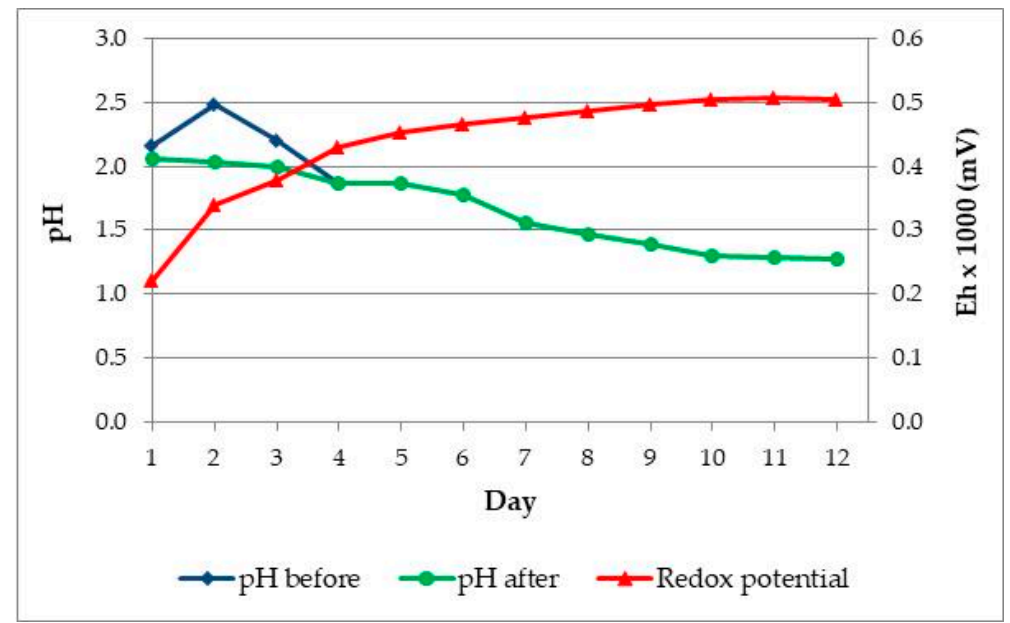

Figure 3. The changes $\mathrm{pH}$ and $\mathrm{Eh}(\mathrm{mV})$ vs. time in Adaptation II. Black circles- $\mathrm{pH}$ before $\mathrm{H}_{2} \mathrm{SO}_{4}$ addition; blue squares- $\mathrm{pH}$ after $\mathrm{H}_{2} \mathrm{SO}_{4}$ addition; red triangles- $\mathrm{Eh}(\mathrm{mV})$.

For the reason increased the $\mathrm{pH}$ value, in first four days, it was adjusted using sulphuric acid to the initial value $\mathrm{pH}=2$.

\subsubsection{Adaptation III}

After the second adaptation experiment, $1 \mathrm{~mL}$ of bacterial cultures was once again transferred to flasks with fresh medium and ore samples. The content of solid in solution was increased to $10 \%(w / v)$. Temperature and stirring speed were constant. Figure 4 shows changes of $\mathrm{pH}$ and $\mathrm{Eh}(\mathrm{mV})$ during third adaptation experiment. The $\mathrm{pH}$ value is also adjusted using sulphuric acid to the initial value $\mathrm{pH}=2$ in first four days.

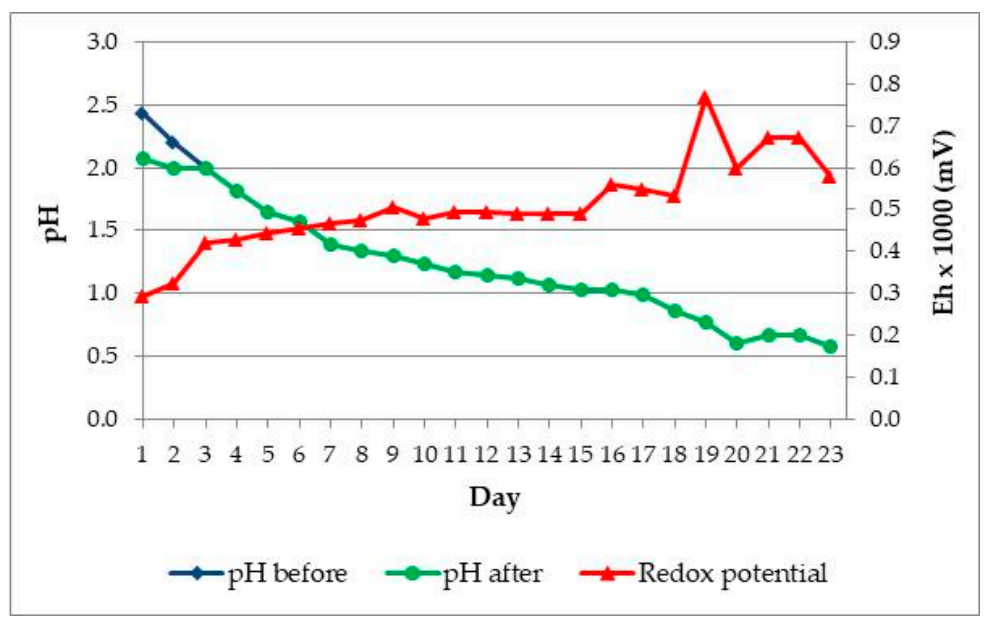

Figure 4. The changes $\mathrm{pH}$ and $\mathrm{Eh}(\mathrm{mV})$ vs. time in Adaptation III. Black circles- $\mathrm{pH}$ before $\mathrm{H}_{2} \mathrm{SO}_{4}$ addition; blue squares- $\mathrm{pH}$ after $\mathrm{H}_{2} \mathrm{SO}_{4}$ addition; red triangles - Eh (mV). 
Addition of polymetallic ore to the basal salts solution increased redox potential to nearly $250 \mathrm{mV}$. During the adaptation experiment, redox potential increased to a maximal value of approx. $500 \mathrm{mV}$. Redox potential of the solution during bioleaching mainly depends of $\left[\mathrm{Fe}^{3+}\right] /\left[\mathrm{Fe}^{2+}\right]$ ratio. Due to oxidative activity of acidophilic iron-oxidizers concentration of $\mathrm{Fe}^{3+}$ ions increases, while concentration of $\mathrm{Fe}^{2+}$ ions decreases, resulting in increase of redox potential of the solution.

\subsection{Laboratory Bioleaching Test}

After, the adaptation bioleaching tests were done in triplicate with one control sample. The bacterial inoculums from the third adaptation is used in the volume of $10 \%(v / v)$. Nutrient medium was basal salts $9 \mathrm{~K}$ used for volume of $1 \mathrm{~L}$. Quantities of polymetallic ore of $100 \mathrm{~g} / \mathrm{L}$ where solids content of the pulp was $10 \%(w / v)$. The value of the redox potential ORP dropped to an initial value of $300 \mathrm{mV}$. The test was continued under the same conditions as during the culture adaptation in a $2 \mathrm{~L}$ glass reactor with a work volume of $1 \mathrm{~L}$ at $250 \mathrm{r} / \mathrm{min}$ and a temperature of $30^{\circ} \mathrm{C}$. Air and carbon dioxide are introduced with the aim of using oxygen $0.5 \mathrm{NL} / \mathrm{min}$ and $\mathrm{CO}_{2}=20 \mathrm{~mL} / \mathrm{min}$, respectively through diffusers. At the beginning of the bioleach process, acidity of the solution was corrected to $\mathrm{pH} 2$ by adding $1 \mathrm{~mol} / \mathrm{L}$ of sulphuric acid. Distilled water was added into the reactor to compensate for the evaporation of the process water.

The redox potential of bioleach solution typically was measured with a platinum electrode versus $\mathrm{Ag} / \mathrm{AgCl}$ (saturated $\mathrm{KCl}$ ) reference electrode. The potential was gradually increased from 300 to $550 \mathrm{mV}$. The change in the ORP value was followed by the increase in the $\mathrm{Cu}$ and $\mathrm{Zn}$, concentrations in the solution. After 20 days of mesophilic leaching, the extraction efficiency remained at the same level. By leaching of $100 \mathrm{~g} / \mathrm{L}$ of ore, the final concentration of the metals of $0.2 \mathrm{~g} / \mathrm{L} \mathrm{Cu}$ and $0.9 \mathrm{~g} / \mathrm{L} \mathrm{Zn}$ were achieved. Recoveries of $\mathrm{Cu}$ and $\mathrm{Zn}$ are presented in Figure 5 and shows that $90 \%$ and $72 \%$ can be achieved, respectively.

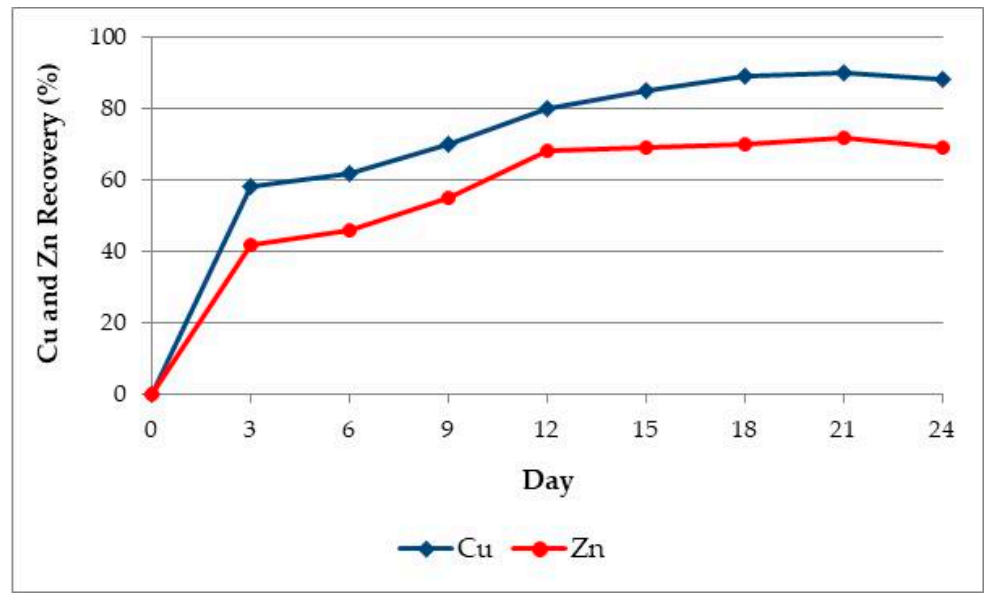

Figure 5. Copper and Zinc recovery vs. time with pulp density of $10 \%(w / v) ; 30{ }^{\circ} \mathrm{C} ; \mathrm{pH} 2$ on the start of process; Nutrient medium solution 9K; Air $0.5 \mathrm{NL} / \mathrm{min}$ and $\mathrm{CO}_{2}=20 \mathrm{~mL} / \mathrm{min}$.

\subsection{Mineralogical Analysis of Solid Residue}

Minerallogy and bioleaching tests are done to identify metals associations in sulphide ores. Parameter control can show the sequence of metal release as consequence bioleaching process. This sequence correlates with the rest potential of the sulphides. Sphalerite (ZnS) with its low rest potential typically is one of the earliest sulphides to oxidize. Mineralogy of copper ofen allows its easy dissolution in bioleaching process. When the ore contains chalcopyrite, copper extraction will be incomplete upon bioleaching with mesophilic micro-organisms using very fine grinding. Bioleaching 
with thermophiles may be required to achieve a high extent copper extraction. The next chemical reactions from (3) to (6) show partial oxidation of the sulphides:

$$
\begin{gathered}
\mathrm{FeS}_{2}+7 \mathrm{O}_{2}+2 \mathrm{H}_{2} \mathrm{O} \leftrightarrow 2 \mathrm{FeSO}_{4}+2 \mathrm{H}_{2} \mathrm{SO}_{4} \\
\mathrm{ZnS}+0.5 \mathrm{O}_{2}+\mathrm{H}_{2} \mathrm{SO}_{4} \leftrightarrow \mathrm{ZnSO}_{4}+\mathrm{S}^{0}+\mathrm{H}_{2} \mathrm{O} \\
\mathrm{CuFeS}_{2}+4.25 \mathrm{O}_{2}+0.5 \mathrm{H}_{2} \mathrm{SO}_{4} \leftrightarrow \mathrm{CuSO}_{4}+0.5 \mathrm{Fe}_{2}\left(\mathrm{SO}_{4}\right)_{3}+0.5 \mathrm{H}_{2} \mathrm{O}, \\
\mathrm{PbS}+1 / 2 \mathrm{O}_{2}+\mathrm{H}_{2} \mathrm{SO}_{2} \leftrightarrow \mathrm{PbSO}_{4}+\mathrm{H}_{2} \mathrm{O}+\mathrm{S}
\end{gathered}
$$

With knowledge of the mineralogy of the prospective ore the laboratory may choose to apply mesophilic or thermophilic organisms in the bioleaching test. If metal extraction is much better with thermophilic micro-organisms it would indicate the necessity of an elevated temperature process for bioprocessing the ore.

From XRD analysis of the solid residue, presented in Figure 6, it can be seen that destruction of the crystal lattice of the starting sample is justified, which justifies the process of bioleaching.

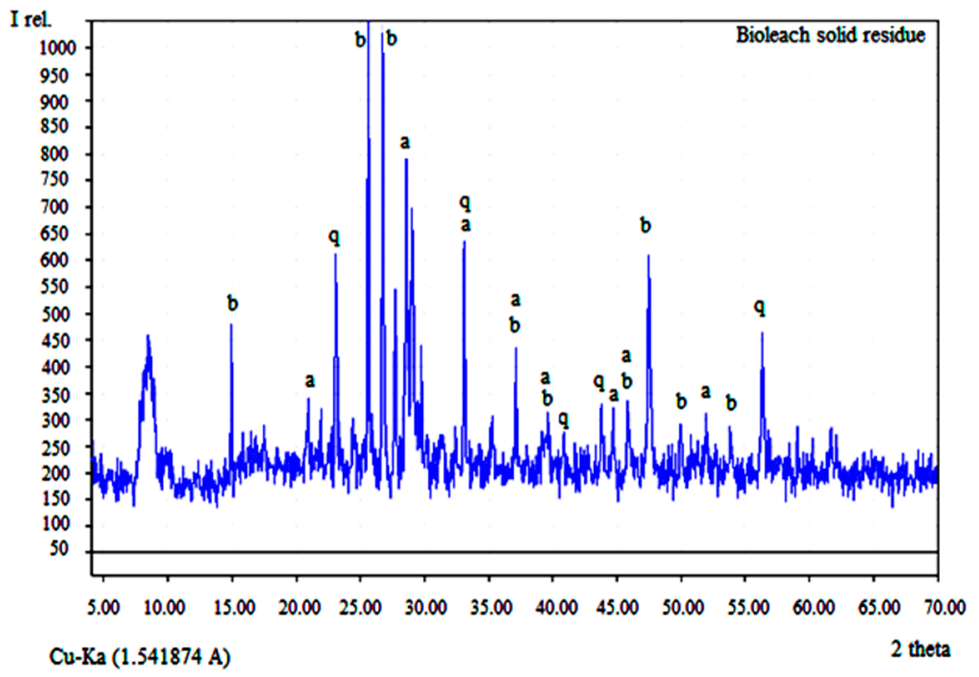

Figure 6. X-ray diffraction pattern of the bioleach residue where a-anglesite; b-beudantite; and q-quartz.

After the bioleaching process, $\mathrm{Cu}, \mathrm{Zn}$ and $\mathrm{Pb}$ are converted into the sulphates. Copper and zinc are dissolve and transfer into solution which is suitable for the next SX-EW process.

Literature data shows that solvent extraction recoveries for $\mathrm{Cu}$ and $\mathrm{Zn}$, can go to the value of $90 \%$ and even over [32].

Today, there are more than 30 copper SX plants in operation recovering over 750,000 tonnes of copper annually from a wide variety of leach solutions. These plants range in size from less than $0.25 \mathrm{~m}^{3} / \mathrm{h}$ aqueous flow up to modules treating about $1440 \mathrm{~m}^{3} / \mathrm{h}$ aqueous flow. The copper SX process has three main objectives: Purification of the copper from unwanted contaminants, concentration of copper values to the point where the final copper recovery process is applicable [33].

\subsection{Lead, Gold and Silver Recovery}

It is determined that from bioleach solid residue over $90 \%$ of $\mathrm{Pb}$ recovery can be achieved using $250 \mathrm{~g} / \mathrm{L} \mathrm{NaCl}$, time of $20 \mathrm{~min}$, temperature of $80^{\circ} \mathrm{C}$ and at phase ratio solid:liquid $=1: 20$ [34].

After lead recovery high extents of recovery are achieved by using environmentally and human friendly technologies for the gold and silver recovery where for the during thiosulphate leaching with 
activator, catalyst and lixiviant addition, $\mathrm{Au}$ and Ag recovery reaches the values over $90 \%$ and $80 \%$, respectively [35].

At the end of bioleaching process optical microscopy of bioleach solution was shown $3.8 \times 10^{9}$ the number of microbial cell. The presence of large number of microbial cell in solution correlates with good microbial growth in the reactor. The use of phase contrast microscopy facilities microscopic examination as cell are easily visible in a simple wet mount. The cell density were determined microscopically using Neubauer chamber using phase contrast microscopy at magnification $(400 \times)$.

In the one of the previous experiments without adaptation, bioleaching efficiency of $83 \%$ and $89 \%$ for $\mathrm{Cu}$ and $\mathrm{Zn}$ respectively were achieved for the 30 days [36].

Also it was found that for the 12 days $88 \%$ and $70 \%$ recoveries for $\mathrm{Cu}$ and $\mathrm{Zn}$ can be achieved without adaptation [37].

The adaptation period allowed further improvement of the bioleaching process at a solids concentration of $10 \%$. As a possible reason for this improvement, a gradual adaptation of the microbiological consortium is indicated, whereby this may be an indication that the microbial consortium is adapted by the mutation of the inherent genes or by obtaining new genes from the horizontal gene pool, leading to increased resistance to the increasing concentrations of both base metals $\mathrm{Cu}$ and $\mathrm{Zn}[3]$.

\subsection{Economic Assessment}

The conducted research of application the bioleaching technology for extraction from the polymetallic mineral deposit Tenka in the laboratory conditions demonstrated an achievement of significant high efficiency metal recoveries, as follows: $\mathrm{Cu} 90 \%$, Au 90\%, $\mathrm{Ag} 80 \%$, Zn 72\% and $\mathrm{Pb} 90 \%$.

The conducted economic assessment, based on the laboratory bioleaching test obtained values of summary metal recoveries, calculated operating costs, metal prices and estimated capital costs (Table A1), was stated through the NPV and IRR, whose values are 21.927 million and $12.55 \%$, respectively.

The following Table 3 and Figure 7 present a numerical and graphical representation of the results of the performed economic analysis.

Table 3. Results of economic analysis performed in software Whittle.

\begin{tabular}{cccccccccc}
\hline Year & $\begin{array}{c}\text { Ore } \\
\text { (tonne) }\end{array}$ & $\begin{array}{c}\text { Waste } \\
\text { (tonne) }\end{array}$ & $\begin{array}{c}\mathbf{C u} \\
\mathbf{( \% )}\end{array}$ & $\begin{array}{c}\mathbf{A g} \\
\mathbf{( g / t )}\end{array}$ & $\begin{array}{c}\mathbf{A u} \\
\mathbf{( g / t )}\end{array}$ & $\begin{array}{c}\mathbf{Z n} \\
\mathbf{( \% )}\end{array}$ & $\begin{array}{c}\mathbf{P b} \\
\mathbf{( \% )}\end{array}$ & $\begin{array}{c}\text { Cashflow } \\
\mathbf{( \$ )}\end{array}$ & $\begin{array}{c}\text { Cashflow } \\
\mathbf{( \$ ~ d i s c )}\end{array}$ \\
\hline 1 & 99,915 & 600,085 & 0.30 & 4.20 & 0.50 & 0.44 & 0.10 & $2,510,645$ & $2,282,404$ \\
2 & 99,998 & 600,002 & 0.22 & 6.30 & 0.50 & 0.74 & 0.11 & $2,491,845$ & $2,059,376$ \\
3 & 100,000 & 331,506 & 0.24 & 8.90 & 0.50 & 1.40 & 0.36 & $3,118,685$ & $2,343,114$ \\
4 & 100,000 & 244,786 & 0.27 & 10.10 & 0.60 & 1.56 & 0.56 & $3,707,067$ & $2,531,977$ \\
5 & 100,000 & 206,138 & 0.26 & 8.90 & 0.60 & 1.33 & 0.45 & $3,383,907$ & $2,101,140$ \\
6 & 100,000 & 99,479 & 0.25 & 7.70 & 0.60 & 1.41 & 0.37 & $3,507,060$ & $1,979,644$ \\
7 & 100,000 & 99,479 & 0.25 & 7.70 & 0.60 & 1.41 & 0.37 & $3,258,800$ & $1,672,280$ \\
8 & 100,000 & 80,866 & 0.27 & 7.80 & 0.70 & 1.06 & 0.26 & $3,735,111$ & $1,742,457$ \\
9 & 100,000 & 104,184 & 0.27 & 8.30 & 0.70 & 1.63 & 0.43 & $3,806,957$ & $1,614,521$ \\
10 & 100,000 & 53,518 & 0.30 & 10.10 & 0.80 & 1.50 & 0.32 & $4,310,576$ & $1,661,914$ \\
11 & 100,000 & 53,518 & 0.30 & 10.10 & 0.80 & 1.50 & 0.32 & $4,310,576$ & $1,510,831$ \\
12 & 29,143 & 15,597 & 0.30 & 10.10 & 0.80 & 1.50 & 0.32 & $1,256,165$ & 428,218 \\
\hline Total & $1,129,056$ & $2,489,158$ & 0.27 & 8.24 & 0.63 & 1.28 & 0.33 & $39,397,394$ & $21,927,876$ \\
\hline
\end{tabular}




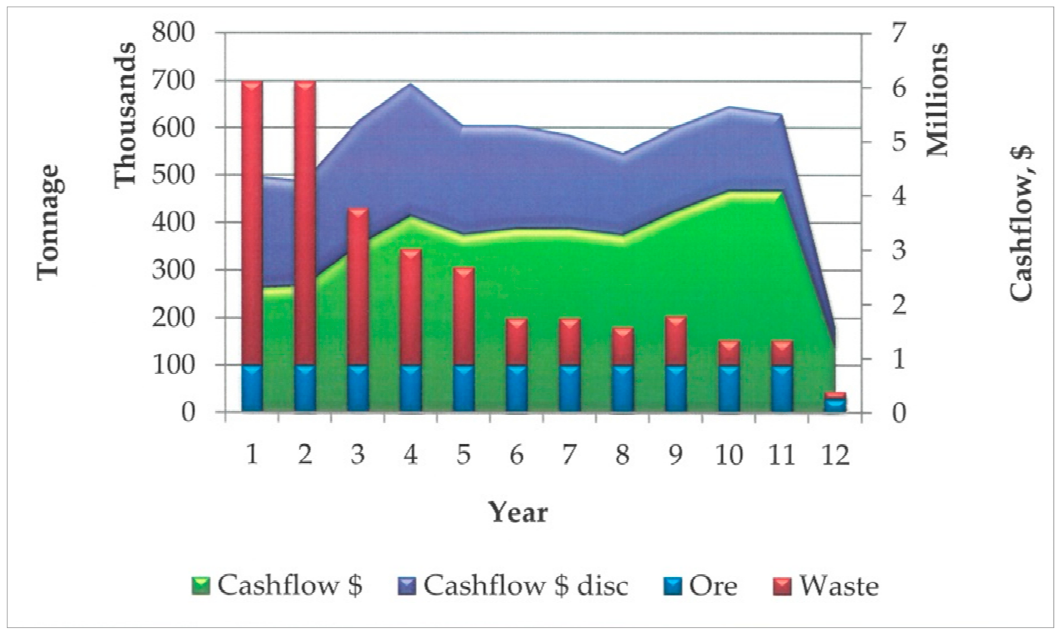

Figure 7. Tonnage of ore and waste and discounted and undiscounted cashflows for the life of the operation.

\section{Conclusions}

The economic potential of the research, which was carried out in this paper, is defined based on the evaluation which was carried out in the software Whittle, which mining companies allow to evaluate the financial viability and the optimal mine strategy for a deposit.

In the example of the deposit Tenka, which consists of the polymetallic ore bodies Tenka 1 and Tenka 2, it has been shown that the significant high metal recoveries were achieved by the use of bioleaching technology in the process of ore processing.

In the conditions of modern business, characterized by the exploitation and processing of low-grade ore, this is one of the basic requirements that the mining company must fulfill in order to achieve the basic goal: maximizing the value that is realized in the integrated process of mining - metallurgy.

In the laboratory bioleaching test is shown that recoveries for $\mathrm{Zn}$ and $\mathrm{Cu}$ can be higher using previous adaptation stages.

In working conditions where the concentration of the solid in the batch was $10 \%$ and the residence time of 20 days using the modified microbial culture, the extraction achieved was 90 and 72 for $\mathrm{Cu}$ and $\mathrm{Zn}$ respectively. High concentration of base metals such as $\mathrm{Cu}$ and $\mathrm{Zn}$ present in polymetallic raw materials may have an inhibitory effect on the behavior of microbes. However, the ability of micro-organisms to adapt and improve their activity after a long-term adaptation program has been demonstrated. This is an important challenge for bioleaching technology to better understand, control and accelerate by the process of adaptation.

Data on metal recoveries, obtained in the process of research work in the laboratory conditions on the polymetallic ore samples of the Tenka deposit, calculated the operating costs for the conducted research and estimated capital costs, were used for calculation the economic measures of values NPV and IRR. The obtained values for NPV and IRR are 21.927 million and $12.55 \%$, respectively.

The economic results of research have encouraged the researchers to continue their scientific research in the semi-industrial conditions on a pilot plant.

Author Contributions: Conceptualization, D.K.; Formal analysis, V.C. and D.B.; Investigation, V.C.; Methodology, D.K., V.C. and I.J.; Project administration, D.B.; Software, D.K.; Writing—review \& editing, D.K.

Funding: This research received no external funding.

Acknowledgments: The authors would like to thank to the Ministry of Education and Science of the Republic of Serbia for the support in realization the Projects No TR33038 and No TR34004, from which the results presented in this paper were ensued.

Conflicts of Interest: The authors declare no conflict of interest. 


\section{Appendix A}

Table A1. Techno-economic parameters for economic analysis.

\begin{tabular}{ccc}
\hline Parameter & Unit & Value \\
\hline Mining capacity & $\mathrm{t} / \mathrm{year}$ & 700,000 \\
Processing capacity & $\mathrm{t} / \mathrm{year}$ & 100,000 \\
Hydrometallurgical processing capacity & $\mathrm{t} / \mathrm{year}$ & 100,000 \\
Mining recovery fraction & & 0.97 \\
Mining dilution fraction & & 1.03 \\
\hline Hydrometallurgical summary recoveries & $\%$ & \\
Copper & $\%$ & 0.810 \\
Gold & $\%$ & 0.800 \\
Silver & $\%$ & 0.648 \\
Zinc & $\%$ & 0.900 \\
Lead & $\%$ & \\
\hline Mining, Processing (Crushing and Grinding) and Hydrometallurgical & & \\
processing cost per tonne of ore for: & $\$ / \mathrm{t}$ & 4180.0 \\
Copper & $\$ / \mathrm{kg}$ & 8702.5 \\
Gold & $\$ / \mathrm{kg}$ & 298.5 \\
Silver & $\$ / \mathrm{t}$ & 1650.0 \\
Zinc & $\$ / \mathrm{t}$ & 1900.0 \\
Lead & & \\
Copper & $\$ / \mathrm{t}$ & 6580 \\
Gold & $\$ / \mathrm{kg}$ & 42,330 \\
Silver & $\$ / \mathrm{kg}$ & 565 \\
Zinc & $\$ / \mathrm{t}$ & 2600 \\
Lead & $\$ / \mathrm{t}$ & 2220 \\
\hline Capital cost [39] & $\$$ & $12,000,000$ \\
Discount rate & $\%$ & 10 \\
\hline & &
\end{tabular}

\section{References}

1. Kumar, A.; Dimitrakopoulos, R. Application of simultaneous stochastic optimization with geometallurgical decisions at a copper-gold mining complex. Min. Technol. 2019, 128, 88-105. [CrossRef]

2. Gholamnejad, J.; Mojahedfar, A.R. Determination of the largest pit with the non-negative net profit in the open pit mines. J. Min. Environ. 2010, 1, 45-52.

3. Gericke, M.; Muller, H.H.; van Staden, P.J.; Pinches, A. Development of a tank bioleaching process for the treatment of complex Cu-polymetallic concentrates. Hydrometallurgy 2008, 94, 23-28. [CrossRef]

4. Rawlings, E.; Johnson, B. The microbiology of biomining: Development and optimization of mineral-oxidizing microbial consortia. Microbiology 2007, 153, 315-324. [CrossRef] [PubMed]

5. Wen-Qing, Q.; Wei-Zhong, L.; Zhuo-Yue, L.; Guan-Zhou, Q. Simulated small-scale pilot plant heap leaching of low-grade oxide zinc ore with integrated selective extraction of zinc. Miner. Eng. 2007, 20, 694-700.

6. Janković, S. Ore Deposits Serbia, Regional Metallogenic Position, the Middle Generation and Types of Deposits; Department of Economic Geology, Mining and Geology, University of Belgrade: Belgrade, Serbia, 1990; pp. 1-760. (In Serbian)

7. Janković, S.; Zarić, P.; Radosavljević, S.; Mojsilović, S.; Jelenković, R. The Basic Geological and Metallogenic Studies in Western Serbia; Study; Republic SIZ for Geological Research: Belgrade, Serbia, 1987; pp. 1-42. (In Serbian)

8. Lučić, J.; Mujezinović, Š. Valorization of Polymetallic Barite-Sulphide Ore from the Bobija Deposit, Near Ljubovija, Study; Study; ITNMS: Belgrade, Serbia, 1973; pp. 1-235. (In Serbian)

9. Radosavljević, S. Mineralogenetic Characteristics of Silver in Pb-Zn deposits Podrinje area. Ph.D. Thesis, Faculty of Mining and Geology, University of Belgrade, Belgrade, Serbia, 1988; pp. 1-264. (In Serbian). 
10. Emsbo, P. Geologic criteria for the assessment of sedimentary exhalative (sedex) Zn-Pb-Ag deposits. US Geol. Surv. Open File Rep. 2009, 1209, 1-21.

11. Leach, D.; Sangster, D.; Kelley, K.; Ross, L.; Garven, G.; Craig, A. Sediment-hosted Pb-Zn Deposits: A global perspective. Econ. Geol. 2010, 105, 593-625. [CrossRef]

12. Johnson, B. Biomining-biotechnologies for extracting and recovering metals from ores and waste materials. Curr. Opin. Biotechnol. 2014, 30, 24-31. [CrossRef]

13. Rawlings, E.; Dew, D.; Plessis, C. Biomineralization of metal-containing ores and concentrates. Trends Biotechnol. 2003, 21, 38-44. [CrossRef]

14. Berezowsky, S.; Collins, J.; Kerfoot, E.; Torres, N. The commercial status of pressure leaching technology. J. Miner. Met. Mater. Soc. 1991, 43, 9-15. [CrossRef]

15. Brierley, L. How will biomining be applied in future? Trans. Nonferrous Met. Soc. China 2008, 18, $1302-1310$. [CrossRef]

16. Brierley, A. A perspective on developments in biohydrometallurgy. Hydrometallurgy 2008, 94, 2-7. [CrossRef]

17. Olson, J.; Brierley, A.; Brierley, L. Bioleaching review. Part, B. Progress in bioleaching: Applications of microbial processes by the minerals industry. Appl. Microbiol. Biotechnol. 2003, 63, 249-257. [CrossRef] [PubMed]

18. Kržanović, D.; Conić, V.; Stevanović, D.; Kolonja, B.; Vaduvesković, J. Long-term planning for open pits for mining sulphide-oxide ores in order to achieve maximum profit. Arch. Min. Sci. 2017, 62, 807-824. [CrossRef]

19. Whittle, G. Enterprise optimisation. In Proceedings of the Mine Planning and Equipment Selection (MPES) Conference, Fremantle, WA, Australia, 1-3 December 2010; pp. 105-117.

20. Whittle, G.; Burks, S. Simultaneous mining and mineral processing enterprise optimization for the platinum industry. In Proceedings of the 4th International Platinum Conference, Platinum in transition "Boom or Bust", Johannesburg, South Africa, 11-14 October 2010; pp. 329-338.

21. Burks, S. Case studies of simultaneous mining and mineral processing optimization applied to platinum and nickel operations. J. S. Afr. Inst. Min. Metall. 2013, 113, 221-233.

22. Peevers, R.; Whittle, G. Enterprise optimization for mining businesses. In Proceedings of the SME Annual Meeting \& Exibit and CMA 115th National Western Mining Conference, Denver, CO, USA, 24-27 February 2013.

23. Erarslan, K. Computer Aided Ore Body Modelling and Mine Valuation. In Earth Sciences; Imran, A.D., Ed.; InTech Europe: Rijeka, Croatia, 2012; pp. 345-372.

24. Software GEMS, version 6.8; Dassault Systèmes Geovia: Vancouver, BC, Canada, License Number LN00025718423.

25. Software Whittle, version 4.7; Dassault Systèmes Geovia: Vancouver, BC, Canada, License Number LN00018697091.

26. Kržanović, D.; Kolonja, B.; Stevanović, D. Maximizing the net present value by applying an optimal cut-off grade for long-term planning of the copper open pits. Acta Montan. Slovaca 2015, 20, 49-61.

27. Whittle, G.; Stange, W.; Hanson, N. Optimising Project Value and Robustness. In Proceedings of the Project Evaluation Conference, Melbourne, Australia, 19-20 June 2007; pp. 1-10.

28. Whittle, J. Beyond optimization in open pit design. In Proceedings of the First Canadian Conference on Computer Applications in the Mineral Industry, Rotterdam, The Netherlands, 7-9 March 1988; pp. 331-337.

29. Whittle, J. A decade of open pit mine planning and optimisation-The craft of turning algorithms into packages. In Proceedings of the APCOM'99: Computer Applications in the Mineral Industries: 28th International Symposum, Golden, CO, USA, 20-22 October 1999; pp. 15-24.

30. Lerchs, H.; Grossmann, I.F. Optimum design of open pit mines. Can. Min. Metall. Bull. 1965, 58, 17-24.

31. Gaupp, M.P. Methods for Improving the Tractability of the Block Sequencing Problem for Open Pit Mining. Ph.D. Thesis, Colorado School of Mines, Golden, CO, USA, 2008.

32. Kordosky, G.; Sierakoski, J. The LIX 860 series: Unmodified Coper extraction reagents. In Proceedings of the International Solvent Extraction Conference, Denver, CO, USA, 26 September 1983; pp. 1-8.

33. Sheinman, R.; Kokotov, Y.; Braginsky, L.; Riordan, J.; Vancas, M. Mass transfer efficiency in sx mixers. In Proceedings of the Alta 2013 nickel-cobalt-copper sessions, Perth, Australia, 29 May 2013; pp. 151-159.

34. Conić, V.; Pešovski, B.; Cvetkovski, V.; Stanojević-Šimšić, Z.; Dragulović, S.; Simonović, D.; Dimitrijević, S. Lead sulphate leaching by sodium chloride solution. Hemijska Ind. 2013, 67, 485-494. (In Serbian) [CrossRef] 
35. Milanovic, D.; Dragulovic, S.; Conic, V.; Kovacevic, R.; Bugarin, M. Chemical refining process for Pb, Au and Ag recovery by treatment of a bioleach solid residue from sedex type ore: Part 2; Chapter 6. In Proceedings of the the IMPC 2018, Moscow, Russia, 17-21 September 2018; pp. 537-543.

36. Conić, V.; Rajčić Vujasinović, M.; Trujić, V.; Cvetkovski, V. Copper, zinc, and iron bioleaching from a polymetallic sulphide concentrate. Trans. Nonferrous Met. Soc. China 2012, 24, 3688-3695. [CrossRef]

37. Conić, V.; Trujić, V.; Dragulovic, S.; Milanovic, D.; Kovacevic, R.; Bugarin, M. Two stage leaching process for $\mathrm{Cu}$ and Zn recovery from sedex type ores: Part 1. In Proceedings of the IMPC 2018, Moscow, Russia, 17-21 September 2018; p. 185.

38. World Bank Commodities Price Forecast. Available online: http://pubdocs.worldbank.org/en/823461540394173663/ CMO-October-2018-Forecasts.pdf (accessed on 24 April 2019).

39. HORIZON. Integrated Innovative Metallurgical System to Benefit Efficiency Polymetallic, Complex and Low Grade Ore and Concentrates; Contract No. 689515; European Project; IntMet: Seville, Spain, 2019.

(C) 2019 by the authors. Licensee MDPI, Basel, Switzerland. This article is an open access article distributed under the terms and conditions of the Creative Commons Attribution (CC BY) license (http://creativecommons.org/licenses/by/4.0/). 